\title{
Public/Private Partnership and Tariff Regulation Failure: The Example of Dakar/Diamniadio Toll Highway in Senegal Elhadji Mounirou Ndiaye*
}

University of Thies, Thies, Senegal

\begin{abstract}
This article shows that the social benefits can be annihilated by a bad negotiation or a regulation failure resulting in an over-tariffication. The example of the toll highway Dakar/Diamniadio in Senegal is revealing. This article gives an analysis as well as an economic and financial evaluation showing that the State had additional margins in tariffs negotiation.
\end{abstract}

Keywords: Public/private partnership; Regulation; Updated evaluation; Over-tariffication

\section{Introduction}

Within the context of the liberalization of its economy started in 1985 , Senegal engaged in the 2000s in new projects under the regime of public/private partnerships (PPP). Prior to that, the liberalization process lead to the privatization in 1996 of Sonatel (National Company of Telecommunications) and in 1998 of Senelec (National Company of Electricity). However, as shown by Casadella's, Liu's, Uznidis' latest works, the result of the liberalization is mitigated in developing countries and this failure is attributed to the lack of institutional capacities. This situation corroborates the acknowledgement of complexification in terms of governance requested by the PPP. That is what Rowe [1] and Giauque [2] notice by showing the little interest, and even competence from political authorities in solving problems related to urging private partners to more transparency so as to ensure a more effective coordination.

This article is an illustration which focuses on the analysis of service tariffication in the context of the Public/Private Partnerships that the State of Senegal agreed on in 2006 with Eiffage/Senegal for the construction and the exploitation of a highway between Dakar and Diamniadio (around $40 \mathrm{~km}$ ). The first section of the article shows a normative approach of the PPP tariff regulation as well as of a summary of the different PPP formulas and their characteristics. The choice of the formula is very important because it determines the level of tariff within the duration of concessions. In our case, even if the concession seems to be a Design Build and Operate (DBO) type as we explain it in 3.1., the formula declared is Build Operate and Transfer (BOT) where the operator is responsible for investments, building and exploitation up to the term of the concession. The interest of this kind of formula is that Senegal will appropriate an important highway after the duration of the concession which is thirty years.

The second section conducts an optimality analysis of that highway tariffication through a financial evaluation using updating mechanisms based on a simplified method of inflation and cars fleet forecast over the thirty years of that concession known as Build Operate and Transfer (BOT).

\section{Theoretical Bases and Methodology}

Private participation raises first the issue of private interests' management in public service works and companies. In fact, the private partner invests money in expectation of incentive compensation. Besides, the expected gain from money invested is the principal determinant in the investment decision according to Francois Leveque [3]. However, the optimality of private participation is measured through its social benefits in relation to the State direct intervention. Consequently, users deserve a quality service at the best price. Such are the interests, widely antagonistic, that the regulator must conciliate.

\section{Public/private partnership and normative approach of tariff regulation}

The determination of the tariff is the main source of social distortions, especially in poor countries where regulators lack experience and are not independent enough from the political power. Laffont [4] considers that in a regime characterized by corruption risk and a lack of qualification, the best way for the regulator to reduce the impact of asymmetric information is to resort to a strict tariff control.

Demsetz [5] had written that regulation is not necessary if the selection mechanism of the private partner is well organized. As for Williamson [6], whatever precautions are taken in an ex ante concession attribution, there is an ex post moral risk which requires an independent regulation. Nevertheless, the regulator must be prepared to have attributes of accuracy, transparency and impartiality. He must be equipped enough to get the right information on the operators'costs so as to get to a fair tariffication which is matched with precise incentives in terms of profitability and productivity.

In order to combine optimality and incentives, the regulator must target a cost which is the closest to the marginal while taking into account the dimensions of uncertainty as well as incomplete and asymmetric information. The regulator's objective is to maximize the social surplus, from which the cost of the public funds $(\mathrm{T})$ necessary to the company budget balance must be subtracted. We assume that these public funds integrate the regulation costs $\left(\mathrm{C}_{\mathrm{r}}\right)$ that are not taken into account in Laffont's models:

*Corresponding author: Elhadji Mounirou Ndiaye, Lecturer, University of Thies, Thies, Senegal, Tel: 00221773790111; E-mail: ehmndiaye@univ-thies.sn; elhadjimounirou@gmail.com

Received November 09, 2017; Accepted November 29, 2017; Published December 01, 2017

Citation: Ndiaye EM (2017) Public/Private Partnership and Tariff Regulation Failure: The Example of Dakar/Diamniadio Toll Highway in Senegal. Int J Econ Manag Sci 7: 495. doi: 10.4172/2162-6359.1000495

Copyright: @ 2017 Ndiaye EM. This is an open-access article distributed under the terms of the Creative Commons Attribution License, which permits unrestricted use, distribution, and reproduction in any medium, provided the original author and source are credited. 
$\mathrm{T}=\mathrm{C}_{\mathrm{r}}+\mathrm{S}_{\mathrm{b}},\left(\mathrm{S}_{\mathrm{b}}\right)$ being the money transferred to the operator.

The regulator's Objective function is: $\mathrm{W}=\mathrm{S}(\mathrm{q})-\mathrm{C}(\mathrm{q})-\lambda \mathrm{T}=\mathrm{S}(\mathrm{q})-\mathrm{C}(\mathrm{q})$ $-\lambda\left(\mathrm{C}_{\mathrm{r}}+\mathrm{S}_{\mathrm{b}}\right)$

where $\mathrm{S}(\mathrm{q})$ is the consumers' surplus, $\mathrm{C}(\mathrm{q})$ the cost of production and $\left(\mathrm{T}=\mathrm{C}_{\mathrm{r}}+\mathrm{S}_{\mathrm{b}}\right)$ the engaged public funds.

The operator's benefit is: $\pi=P(q) q-C(q)-\varphi(e)+S_{b}$, where (e) is the effort of reduction of the costs (private information of the company) and $\varphi(e)$ is the monetary equivalent of the uselessness of the operator's efforts to reduce the costs.

Laffont and Martimore's model [7] establishes that it is possible to determine the optimal tariff so that the applied price verify LernerRamsey-Boiteux rule: $\frac{P(q)-C}{P(q)}=\frac{\lambda}{1+\lambda} \frac{1}{\varepsilon_{i}}$ (where $\varepsilon_{\mathrm{i}}$ is the price-elasticity
of (the) demand).

Laffont and Martimort underline that $(\boldsymbol{\lambda})$ is not Lagrange's endogenous multiplier (which is the marginal utility of money transfers), but is the cost of public funds basically justified by the tax system imperfections (costs of collection) ${ }^{1}$. It is therefore an arbitration model between internal profitability and budgetary compensation. This model is of particular interest in taking into account issues of adverse selection and moral hazard. The moral hazard is removed by the presumed observability of the operator's costs but the adverse selection subsists.

Finally, we can retain that main sectors must be under supervision of an independent regulator. Moreover, since Ramsey-Boiteux's repartition can be executed, the regulator's global program is then ex ante to get from the operator that he maximizes his productivity and to limit his informational income (or the benefit from the asymmetry of information).

\section{Methodology}

Tariff regulation is based on theoretical formulas depending on the type of PPP used. The following Table 1 summarizes the main PPP formulas and their characteristics. It will serve as a compass to help us qualify and analyze the type of partnership that Senegal developed in the framework of Dakar/Diamniadio highway. We are going to test the hypothesis showing that the absence of an appropriate mechanism of tariff regulation led to an over-tariffication of this highway, which reduced the incentive character of the contract and led to a loss of global surplus [8-10].

In a DBO type contract the period and the tariffs are less high since public funds are used almost entirely in the completion of the work. The same pattern is observed with the Dakar/Diamniadio highway, which we are going to test the hypothesis of an overtariffication for the targeted period (30 years).

We will compare the updated financial participation of the private partner with his updated revenues over a period of 30 years. To achieve this, we will index the traffic evolution on cars fleet growth over a period of 30 years. As for predictable tariffs revisions, we are going to correlate them with an average estimation of the inflation over a period of 30 years. The inflation forecast can be based on simple patterns which regress the growth of consumer price index (CPI) with respect to its past values.

These patterns incorporate other indicators (IND) such as raw materials prices, financial indicators (exchange, monetary aggregates, etc.) as well as indicators of real economy such as the use of production capacities, unemployment and the average hourly wage.

$$
\Delta I P C_{i}=\alpha+\sum_{t-i}^{4} \beta \Delta I P C_{t-i}+\delta I N D_{t-i}+\varepsilon
$$

The use of patterns requires quarterly data. Cecchetti, Chu, Streindel used it in the United States with data from the first quarter of 1975 to the end of 1984, so as to get inflation forecasts for the eight quarters of the period 1985-1986. Therefore, it is a constraining mechanism which is difficult to implement in Senegal for a period of 30 years. We will then be satisfied with a simplified correlation to have a global average evolution of inflation and car fleet for 25 to 30 years (Box 1).

\section{The example of over-tariffication of Dakar/Diamniadio toll highway}

We will notice that in this case the absence of adequate regulating mechanisms has given way to the private partner to applicate an overtariffication. For this, we proceed by determining averages of tariff and cars fleet evolution for 25 years. Before that, we will show that the financial setting cannot concern a BOT type but a DBO type contract.

\begin{tabular}{|c|c|c|}
\hline Contractual formula & Comprehensive management by the operator for a period between 20 and 30 years. The operator is \\
responsible for most of the investments.
\end{tabular}

Source: From Marty, Trosa et Voisin, 2006, Savas, 1998 et Cahiers Industries (2004).

Table 1: Summary of the main PPP formulas.

1Jullien et Rochet underline that it is about a fundamental measure in Laffont's and Tirole's approach. They quote Hausman and Poterba (1987) who assessed it in the case of the United States to à $\lambda=0,3$.

\section{Survey of the highway financial setting}

For this highway project which cost is about Franc CFA 380 
Citation: Ndiaye EM (2017) Public/Private Partnership and Tariff Regulation Failure: The Example of Dakar/Diamniadio Toll Highway in Senegal. Int J Econ Manag Sci 7: 495. doi: 10.4172/2162-6359.1000495

billion$^{2}$, Senegalese government gave Franc CFA 319 billion. Eiffage/ Senegal contribution amounts to Franc CFA 61 billion in addition to the construction responsibility. A contract named BOT of 30 years was executed on July 2, 2009.

This Table 2 shows that the State of Senegal and its financial partners (government loans) provided $84 \%$ of funding. This strong public contribution discredits the BOT designation of the contract. Eiffage/ Senegal's work is rather centered on the infrastructure conception and implementation. It is rather a DBO type contract (Cf chart 1 ). The Dakar/Diamniadio portion was delivered since 2011 and the remaining part was available from August 2013 onwards. as follows: FCFA 800 for two-wheeled vehicles, FCFA 1,400 for private vehicles, FCFA 2,000 for minibuses and public transportation vehicles, and FCFA 2,700 for trucks and any heavy vehicles. On average $16 \%$ of the traffic on the highway involve public transportation vehicles [11] As a result of field observations, we can state that approximately $60 \%$ of traffic involves private vehicles, $6 \%$ of motorcycles, and $18 \%$ of heavy vehicles.

The average tariff $(\mathrm{AT})$ is then: $(\mathrm{AP}) \mathrm{AT}=0.6 \times 1,400+0.16 \times 2,000+$ $0.06 \times 800+0.18 \times 2,700$, which makes AT $=$ FCFA 1,694 .

If a maximum VAT (Added Value Tax) rate of $18 \%$ is subtracted, the concessionaire collects an average amount of FCFA 1,390 per

To have an average inflation and evolution of car fleet over the next 30 years, we simply made a delayed correlation. Our concern is to obtain a general average of the concerned variables evolution over a period of 30 years.

\section{Inflation}

As for inflation, we then chose the simple linear model with a delayed variable:

$$
\operatorname{lnf}=\alpha_{0}+\alpha_{1} \operatorname{lnf} f_{t-1}+\varepsilon
$$

We used data on the inflation in Senegal from 1980 to 2013. This correlation, which is $90 \%$ significant shows a general tenden cy of rising inflation in Senegal. Its main limitation is its failure to deal with periods of high rise (32\% in 1994) or fall (drop) (-4.1\% in 1987). Inflation being too unstable over the study period, we will ultimately consider the general average over the last 34 years, about $4 \%$ of inflation on average (see annex for details).

\section{Car fleet}

As regards car fleet, statistics are unavailable. But given its permanent rise since 1996, it was possible to use data of the period 19962012 to make a simple forecast until 2037. The correlation with a delayed variable helped in making this forecast of the Senegalese car fleet.

$$
\mathrm{P} \alpha_{\mathrm{t}}=\beta_{0}+\beta 1 \mathrm{P} \alpha_{\mathrm{t}-1}+\varepsilon^{\prime}
$$

Data used here are the results of 17 years of observation (1996-2012) and their analysis with Stata software enabled to collect results of regression, which helped in the forecast the car fleet value until 2037. The results of regression and the table of expected figures are in annex. They enabled to forecast an average rate of the car fleet evolution of 3.15\% from 2012 to 2037.

\begin{tabular}{|c|c|c|c|c|c|c|}
\hline & Motorway work & Expropriation procedure & Relocation zone & Urban restructuring & $\begin{array}{l}\text { Miscellanuous (Others) } \\
\text { (studies, control, etc.) }\end{array}$ & Total \\
\hline \multicolumn{7}{|c|}{ Phase 1 : Malick SY-Patte d'Oie/Pikine } \\
\hline Senegal & 82.8 & 18.6 & & & 5.9 & 107.3 \\
\hline \multicolumn{7}{|c|}{ Phase 2: Pikine/Diamniadio } \\
\hline Senegal & 37.8 & 37.4 & 5.4 & & 5.6 & 86.2 \\
\hline WB & & 11.1 & 18.2 & 13.6 & 9.6 & 52.5 \\
\hline AFD & 16.4 & & 12.6 & 9.4 & 1.6 & 40 \\
\hline BAD & 33.2 & & & & & 33,2 \\
\hline Eiffage & 61 & & & & & 61 \\
\hline Total & 231.2 & 67.1 & 36.2 & 23 & 22.7 & 380.2 \\
\hline
\end{tabular}

Box 1: Estimation of average rates of evolution of the tariffs and automobile fleet from 2012 to 2037.

Source: APIX (WB=World Bank, BAD=African Development Bank).

Table 2: Dakar/Diamniadio highway financing (in billions F CFA).

\section{Analysis of the Highway Tariffication}

Let us agree on a $7 \%$ discount rate over 30 years. Therefore, the FCFA 61 billion injected by Eiffage/Senegal represent a current value of FCFA 464 billion. This amount is to be compared with the updated average of potential revenues over 30 years of exploitation. Tariffs are

${ }^{2}$ Franc CFA is Senegalese currency, shared by member states of the Economic Union of West African States (EMUWA) transaction. Statistics show an initial traffic of 40,000 vehicles per day, which is about 50,000 transactions daily from 2013 . Our inflation and car fleet forecasts give respective average growths of $4 \%$ and $3 \%$ in the next 30 years (Box 1 and Table 3 ).

In terms of current value and according to tariffication applied, Dakar/Diamniadio highway will yield revenues of at least FCFA 2,256 billion in 30 years. So, the capital pay-back period is less than 8 years. 
Citation: Ndiaye EM (2017) Public/Private Partnership and Tariff Regulation Failure: The Example of Dakar/Diamniadio Toll Highway in Senegal. Int J Econ Manag Sci 7: 495. doi: 10.4172/2162-6359.1000495

Page 4 of 4

\begin{tabular}{|l|c|c|}
\hline & Toll rate & Total number of transactions \\
\hline Total value over 30 years & $1390 \frac{1-(1,04)^{30}}{1-1,04}=77958$ & $50000 \times 365 \frac{1-(1,03)^{30}}{1-0,03}=868335000$ \\
\hline Annual average & F CFA 2,598 & 28944500 transactions \\
\hline Average of total revenues expected over 30 years $=28944500 \times 2598 \times 30=F C F A ~ 2256$ billion & \\
\hline Current value of 61 billion $(7 \%$ over 30 years $)=61$ billion $\times 7,6123=F C F A 464$ billion & \\
\hline
\end{tabular}

Table 3: Calculation table of updated cash flow.

That period is less than two years for the FCFA 61 billion injected by Eiffage/Senegal. The BOT convention, in its article 21, allows the operator to conduct additional activities such as the exclusive contract award for gas stations implementation on highway. However, it is essentially an evaluation with a clear future, not taking into account potential hazard, especially country risk and traffic risk. In addition, it does not take into account traffic-jam effects, which an upheld tariff could help solve. The margin of error agreed relatively in correlation with inflation and the car fleet is $10 \%$. But this evaluation uses a low evolution rate of the car fleet, which was around $11 \%$ between 2009 and 2010 [12].

The low evolution rate of the car fleet agreed on $3.15 \%$ enables to take into account a hypothetical fall of personal transportation opportunities generated by the improvement strategies of public transportation such as the Regional Express Train (TER) being implemented between AIDB (Blaise Diagne International Airport) and Dakar. Besides, whatever the level of control of revenues and exploitation costs by the State, the tariffs and the concession period are proving to be too high for a highway financed with $84 \%$ of public funds. The State should learn from it for the tariffication of ongoing works.

\section{Conclusion}

PPP enables the States to have access to modern infrastructures they appropriate at the end of contracts. Yet, a question remains: Do users' complaints about quality and tariff of services confirm the still unseen hypothetical effects of private participation? From a social perspective, liberalization has not born the expected fruits yet as testified in the latest works of Casadella, Liu, and Uzunidi. The case of Dakar/Diamniadio toll highway in Senegal reflects the problems of transparency in the PPP highlighted in several scientific works [13].

Transparency is an objective to reach. The same is true for the State in its ability to monitor and regulate these new forms of coordination [14].

In this case of Senegal, the over-tariffication hypothesis has been verified. Besides, the initial presentation of the different PPP formulas, their characteristics and the normative approach of tariff regulation lead to a general remark: a weak appropriation of the theoretical tools in the regulation mechanisms of the PPP in Senegal $[15,16]$. The Senegalese transportation sector needs to have an independent regulator with responsibilities from the attribution phase ex ante of the highway concessions to the regulation ex post of services.

\section{References}

1. Rowe M (2006) Abusive partnerships. New forms of governance, new forms of abuse? International Journal of Sociology \& Social Policy 26: 207-219.

2. Giauque D (2009) The difficulties of managing public-private partnerships in Europe. Revue française d'administration publique 130: 383-394.

3. Leveque F, Yann M (2004) Regulatory economics. Col Repères, 128 pages, Paris.

4. LaffonT JJ (1996) Privatisation et incitations. Revue Economique 6: 1239-1251.

5. Demsetz H (1968) Why Regulate Utilities? Journal of Law and Economics 11: $55-66$.

6. Williamson OE (1979) Transaction-Cost Economics: The Governance of Contractual Relations. Journal of Law and Economics 22: 3-61.

7. Laffont JJ, Martimort D (2002) The Theory of Incentives: The principal Agent Model, Princeton University Press, USA.

8. Guasch JL, Laffont JJ, Straub S (2006) Renegotiation of concession contracts: a theoretical approach. Review of Industrial Organization 1: 55-73.

9. Guasch JL, Laffont JJ, Straub S (2007) Concessions of infrastructures in Latin America: government-led renegotiation. Journal of Applied Econometrics 22: 421-442.

10. Guasch JL, Laffont JJ, Straub S (2008) Renegotiation of Concession Contracts in Latin America. Evidence from the Water and Transport Sector. International Journal of Industrial Organization 26: 421-442.

11. Senac SA (2015) Public Communication.

12. ANSD (2012) Situation économique du Sénégal en 2010

13. Sadran P (2004) Public-private partnership in France: a polymorphous and unacknowledged category of public policy. International Review of Administrative Sciences 70: 233-251.

14. Jullien B, Rochet JC (2005) Regulation in practice. Revue d'Economie Politique 3: $273-283$.

15. Marty F, Trosa S, Voisin A (2006) Public-private partnerships, Repère, Paris, p: 122.

16. Savas ES (2000) Privatization and public-private partnerships. New Horizon, Paris 